\title{
Article \\ Victimization and Vilification of Romani Children in Media and Human Rights Organizations Discourses
}

\author{
Mary Christianakis \\ Department of Critical Theory and Social Justice, Occidental College, Los Angeles, CA 90041, USA; E-Mail: mary@oxy.edu
}

Submitted: 23 February 2015 | Accepted: 2 May 2015 | Published: 29 September 2015

\begin{abstract}
Through an analysis of European newspapers, human rights organization reportage, and United Nations documents and websites, this article examines how public discourse regarding education, human rights, poverty, child rearing, and child labour manufactures a dangerous, implausible childhood for Romani children. These discourses, perpetrated by human rights organizations and news media, leverage the languages of intervention, cultural difference, nationalism, and social justice to simultaneously victimize and vilify Romani children, rendering them incapable of experiencing humane childhoods. Employing critical discourse analysis and systemic functional grammar analysis, the proposed article seeks to disentangle the discourses of human rights for Roman children from the assimilationist arguments aimed at compulsory schooling and Eurocentric family and labour practices rooted in access to middle class dominant labor markets.
\end{abstract}

\section{Keywords}

children; discourse; human rights organization; media; news; Roma; victim; villain

\section{Issue}

This article is part of the special issue "Talking about Roma: Implications for Social Inclusion", edited by Dr. Eben Friedman (Independent Consultant and Senior Non-resident Research Associate, European Centre for Minority Issues, Germany).

(C) 2015 by the author; licensee Cogitatio (Lisbon, Portugal). This article is licensed under a Creative Commons Attribution 4.0 International License (CC BY).

\section{Introduction}

The solid ground of the earth is delineated by fences, enclosures, boundaries, walls, houses, and other constructs. Then the orders and orientations of human social life become apparent. (Carl Schmitt, 2003 p. 46)

The April $4^{\text {th }} 2012$ issue of the Swiss magazine Die Weltwoch features a close-up picture of a very young Roma boy pointing a gun straight into the camera of Italian photographer Livio Mancini. Underneath reads the article headline: "They come, they steal and they go." Die Weltwoch proceeds to claim that, "Roma families from Eastern Europe are responsible for a large part of increasing crime tourism." Deputy Editor and article co-author, Phillip Gut, asserts that "crime tourism" in Switzerland is largely carried out by Roma gangs, telling the Swiss newspaper Sonntags Zeitung that "the child in the photograph symbolized the fact that Roma gangs misuse their children for criminal purposes" (Dewsbury, 2012, para. 4). Mr. Gut forgot to mention that the child was holding a toy gun-and that most Roma families are neither "tourists" nor "criminals." In 2010, French President Nicolas Sarkozy ordered 300 Roma camps closed, describing them as "sources of illegal trafficking, of profoundly shocking living standards, of exploitation of children for begging, of prostitution and crime" (BBC, 2010). Half a decade earlier, the British tabloid The Sun published an article entitled, "Sun War on Gipsy Free for All," (Barkham, 2005, para. 1) featuring the image of a Roma child entering a ramshackle trailer parked in a run-down trailer park. The discursive framing of Roma children as criminal, poor, dirty, and unsupervised creates a unique discursive cultural cast for the Roma, facilitating the dehumanization they have recently experienced at the hands of dominant European nations.

Simultaneously, and somewhat ironically, the public narratives of Roma children construct them as the 
most victimized children in all of Europe, in need of protection from their parents, guardians, and both social and governmental institutions so that they may attain full democratic participation. The World Bank (2005) has published an exhaustive report entitled, "Roma in an Expanding Europe: Breaking the Poverty Cycle." This report constructs Roma identity in Europe as a problem of poverty at the nation-state level. They argue that "[p]olicies to address Roma poverty...need to be an integral component of each country's economic and social development strategies (p. xiii). Similarly, the last ten years have been marked by a series of stories and reports demonstrating the startling marginalization of these children. For example, a 2005 United Nations Children's Fund Report cites culturally irrelevant pedagogy and discrimination in Bosnia and Herzegovina as the reasons why 80 percent of Roma children do not attend school and instead enter the labour force, working in unsuitable conditions and for unfair wages (United Nations Children's Fund, 2005, p. 28). Three years later, the news in 2008 showed two Roma girls, a 14- and 16-yearold, who had drowned to death and lay on a hot sandy beach in Italy covered with flimsy beach towels, while sunbathers continued their relaxation, as their corpses "were carried away on the shoulders [of the officers] between bathers stretched out in the sun" (Hooper, 2008, para 8). Then, in the fall of 2013, 4-year-old Maria, dubbed "the blond angel," was "found" in a Roma camp in Greece, reiterating the fear in Europeans to be fearful of Roma stealing (white) children. The British newspaper The Guardian provided a close up of a beleaguered and ill-kept blond blue-eyed girl after her two alleged parents were arrested for abduction and later found to have falsified birth registrations. The article title reads, "Maria case exposes extent of child trafficking in crisishit Greece" (Smith, 2013). Maria became the angelic face to champion the anti-child trafficking movement in Europe. And most recently, in January of 2015, BBC reported that a Roma baby who died of Sudden Infant Death Syndrome was initially "refused" a burial in Champlan, France because "priority is given to those who pay local taxes," according to the Mayor Christian Leclerc (BBC, 2015, para. 5), who neglected to mention that children do not pay taxes. Reviled and vilified on the one hand and marginalized victims needing protection from both their parents and public institutions on the other, Roma children fight a seemingly impossible battle against their own social construction. Roma children and their childhoods are situated in public narratives of human rights, narratives of poverty and criminality, and narratives of unauthorized migration.

As Foucault (2003) argues, understanding the discursive features of modalities of power and decoupling them from the juridico-institutional bureaucracies operant in nation states may disrupt the power that seeks to disaffirm and disallow particular lives. Self-evident also is that specific language is deployed by govern- mental agents to preserve their geopolitical hegemony. (Hardt \& Negri, 2001). In the case of Roma people, both the human rights organization and popular media discourses have colluded to construct a socially impossible Roma childhood working in contradistinction with the nation state. Roma children's childhoods are conceptualized through European ideals wherein the complex cultural practices of Roma children are obfuscated as to preserve the normative archetype of the European child. Roma childhoods stand in contrast to the "normal" European childhoods and therefore need intervention from advocates. The construction of a normal childhood and the disidentification with that childhood by the Roma is produced because the norm invokes "multiple separations, individualizing distributions, an organization in depth of surveillance and control and intensification and ramification of power" (Foucault, 1977, p. 198). Outside the European norm, Roma children and childhoods can only be understood in a place of alterity. For those children whose lives are different from that of the hegemonic norm, childhood is a project doomed to failure by a discourse that constructs their impossibility.

The number of Roma in Europe is estimated to be between 10 and 12 million, with over half residing in the European Union, making them the largest minority group in Europe (Martinidis, Andrei, \& Tkadlecova, 2014). Through an analysis of European newspapers, human rights organization reportage, and United Nations documents, this article examines how the publicly conducted philanthropic discourses of education, human rights, poverty, child rearing, and child labour fashion an implausible and dangerous childhood for Romani children. These discourses, emerging out of a neoliberal zeitgeist, leverage the languages of intervention, cultural difference, nationalism, and social justice to relinquish responsibility over and victimize Romani children, rendering them incapable of experiencing humane childhoods and leaving them unprepared them for adulthood.

Employing a critical discourse analysis and systemic functional grammar analysis, the present article seeks to disentangle the discourses of human rights for Roma children from the assimilationist arguments aimed at compulsory schooling and Eurocentric family and labour practices. In so doing, I aim to show how the wellmeaning discourse of care and protection undermines and limits the fullness of Roma childhoods by constructing them as culturally criminal. The article begins with a brief review of the literature on Roma children and childhoods followed by a discussion of the analytical approaches that inform the critical assessment of the impact of such discourses on Roma Children.

\section{Research on Roma Children and Childhoods}

Much of the research on Roma children explores how 
they fare in comparison to their European counterparts with the goal of assimilating Roma children and helping them gain access to the social and economic benefits regularly utilized by other European children. Some of the research constructs the Roma child as "socially disadvantaged", arguing that "disadvantageous social, language and cultural background produces variability of the child's individual needs and conditions" (Lipnická, 2014 , p. 59). Though well meaning, most studies of Roma children implicitly critique the parents, culture, and society in which they are raised, framing Roma children as perpetual victims in need of political and policy intervention so that their acceptance and proper socialization can be facilitated. Van Baar (2009) argues that such policies and practices intervening on many Roma communities emerge out of Foucault's concept of governmentality, where the state is no longer restricted to matters of state, but may also intervene upon social and cultural life. As such, some of the research on the policies and practices of Roma families may laminate state governmentality on areas not typically subject to state control.

A primary focus of research on Roma children is on the educational resources provided to them. Historically, throughout Europe, Roma children have been segregated and separated in public schools. Researchers and children's rights groups view the educational integration of Roma children as a pathway out of poverty (Járóka, 2007). In response to lobbying from children's rights and Roma rights groups, the Grand Chamber of European Court of Human Rights made a landmark decision on November 13, 2007, ruling that the segregation of Romani students in remedial schools is unlawful and discriminatory. Eight years later, Roma children still face structural inequality, including the lack of equal access to quality schooling. For example, in a three country study of the Czech Republic, Greece, and Romania, Martinidis et al. (2014) found that Roma children are refused enrolment in public schools, overrepresented in special schools for children with disabilities or in substandard schools, and that even when they are placed in ordinary schools, they are likely to be discriminated against through both violence and segregation practices. Similarly, Trimikliniotis and Demetriou (2009) document how separatist school practices in urban cities within Cyprus make high educational attainment impossible for Romani children. Many migrant Roma, not surprisingly, refuse to attend European educational systems, where Roma children face segregationalist practices.

Roma children have not fared well in compulsory public schooling (Cozmas, Cucos, \& Momanu, 2000). In an edited volume, Miscovic (2013) reveals the multiple practices, policies, and politics shaping the problematic education Roma children receive in Europe. An examination of the test score gap between Roma and nonRoma children in Hungary found that along with at- tending lower quality schools, "one-third to two thirds of the test score gap" can be explained by the home environment and the parents' income, wealth and education (2014, p. 2). Family poverty limits Roma children's access to school, as it often leads them to live in remote places (Martinidis et al., 2014). According to a United Nations Dependency Program Survey, Roma girls receive less education than Roma boys because they are more likely to experience poverty, marry, and give birth at an early age (UNDP, 2002). Findings from the study illustrate that Roma girls cease attending school when "the opportunity costs of sending children to school rise in households with falling incomes" (UNDP, 2002, p. 29). The low educational attainment of Roma children translates to low levels of employability skills and hinders them in the labour market (O'Higgins \& Ivanov, 2006). In the literature, however, there is little critique about how the educational settings of most European countries aim to culturally assimilate Roma children against their own wishes and those of their families (Lesar, Čuk, \& Peček, 2006). Little to no attention has been paid to the psychological and psychosocial effects of such discriminatory practices at the hands of the state.

Amongst the Roma, compulsory public schooling is conceptualized as a sociocultural problem. First, schooling is not necessarily linked to social or economic status within some Roma communities and is likely to be deemed disrespectful (culturally and familially), painful, ineffective, and a distraction from familial economic activities necessary for survival. Second, some Roma parents see formal schooling as an invasive and unnecessary intrusion by a society which seeks to control their parenting and their children's lives (Lee \& Warren, 1991). Third, Roma children, for their part, may experience school as boring and irrelevant and have more interest in practical knowledge of everyday life than indoctrination into prioritizing "scholarly knowledge" (Kyuchokov, 2000). As a result, many Roma families opt to stop enrolling their children in school, if they even did so to begin with. Instead, Roma children are taught through apprenticeships (Lave \& Wenger, 1991; Wenger, 1998) that expose them to the cultural practices of their community, including skills that will allow them to make money (Christianakis, 2010). In this way, knowledge construction is communal (Wasko \& Faraj, 2000) and stands in opposition to individualist paradigms, which call for children to be socialized and taught in institutional settings separate from the family.

Research indicates that Roma girls have limited opportunities at home, in educational settings, and in the labour market. Roma families tend to reproduce hegemonic patriarchal structures (Levinson, 2005) wherein girls are taught to abide by paternalistic gender norms that relegate them to domestic and reproductive labour. They reside separate from mainstream society and culture, possibly to become wives and mothers at 
a young age, resulting in little access to good working conditions and thus making welfare dependency more likely (Martinidis et al., 2014). The implicit cultural critique that results from some of the aforementioned research is that Roma culture prepares their girls to live off the dole rather than be gainfully employed in the labour market.

In addition to patriarchal gender acculturation and inadequate educational attainment, research on Roma childhoods construct the Roma families as lacking necessary information and common knowledge about public health and child safety. In a retrospective study of scald burns in children spanning 3 years, $58.7 \%$ of 201 children with scald burns were of Roma ethnicity, and therefore the authors recommended, "organized education of this vulnerable population" (Frisman, Rácz, Petrovicová, Ján Slávik, \& Cimboláková, 2015). Roma children, according to the research, are not only vulnerable because of their living conditions, but also because of Roma health practices. In a comparative study of Roma vs. Non-Roma children in Romania and Bulgaria, "negative effects of Roma family life," such as unsafe living conditions (as determined by the standards of the state where they live), social discrimination, few sanitation amenities, and subpar educational environments predispose Roma children to have higher rates of mental health problems (Lee et al., 2014, p. x). Roma parents are conceptualized as negligent because often they do not register their children's births, and this prevents them from receiving free services, such as vaccinations; therefore, their children are more susceptible to contagious diseases (Kevorkyan et al., 2015; Mellou et al., 2015). There is a focus on the ways in which Roma resistance to vaccination is constructed as a threat to the health safety of the dominant populations in which they live (Hajloff \& McKee, 2000). Within the research, attention to Roma children as public health risks constructs the Roma family as either lacking the basic information or as being negligent of the basic needs of their children and therefore recommendations call for public health outreach campaigns. Such deficit orientations fail to seriously consider that Roma parents may ascribe to very different world views and that unvaccinated Roma children may be indicative of lack of faith in the national governments, limited access to money, and distrust of the medical establishment and governmentally administered medications. There is a need for research that examines the health concerns of Roma people from their own perspectives, and not only from the perspectives of nation states.

Taken together, most of the research on Roma children frames the Roma people as economically and culturally impoverished and in need of governmental intervention and protection. There is little research, however, examining the representations of the Roma in news media and on human rights internet sites. Such research is necessary given that the media influences public discourses of Roma people, constructing what $\mathrm{Pa}$ tricia Hill Collins terms "controlling images," which are the myths and stereotypes that shape how marginalized people are perceived and treated (Hill Collins, 2008).

\section{Feminist Critical Discourse Analysis Methods}

Power and dominance are reproduced and reiterated in varied social arenas, perhaps even unwittingly, through the discourses of well-meaning institutions and the individuals who make them up and run them, such as the news media and non-profit human rights organizations. However, the enactment of power through discourse is not always explicit (Fairclough, 2013; Fairclough \& Wodak, 1997; Lazar, 2007; Van Dijk, 2013). Meanings of particular discourses often belie "hidden agendas," which often are responsible for reproducing inequality (Litosseliti, 2006, p. 56).

This analysis employs the tools of Critical Discourse Analysis (CDA) and Systemic Functional Grammar analysis (SFG) in order to reveal the "structural relationships of dominance, discrimination, power and control as manifested in language" (Wodak, 1995 p. 207), as well as how the social power, dominance, and inequality are enacted, reproduced and resisted by text and talk in the social and political context (Van Dijk, 2013, p. 352). SFG is a "theory of meaning as choice by which a language or other semiotic system is interpreted as networks of interlocking options" or "metafunctions" (Halliday, 1985, p. xiv). Using the emancipatory framework of feminist discourse analysis (Lazar, 2008, Litosseliti, 2006), this CDA and SFG study aims to challenge the linguistic machinery that produces and sustains social inequalities rooted in patriarchal and Western Eurocentric ideologies. Additionally, given that the Roma are and were often represented as a social problem of or created by Europe, I also employed argumentation analysis (Neagu, 2013; Toulmin, 2003; Van Eemeren \& Garssen, 2012), which allowed me to focus on the fallacies and topoi of arguments, perspectivation or framing, which allowed me to interpret the reporting or narration of Roma difficulties, and examination of the illocutionary force of the discourse, which gave access to the unintended meanings. In the spirit of post-colonial feminisms, which allow for the coexistence of disputed meanings and different subject positions, I not only critique representations of Roma people, but also examine discourses of contestation.

The aim of the present analysis is to contest the language and meanings in the newspapers, human rights reports, and United Nations documents that construct Roma children as both victims of the state and victims of their own cultural failing, thus rendering the project of making and living as a Roma child a failed one, rather than one of persistence, resistance, resilience, and strength. 


\section{Methods}

The findings in this article are based on a close analysis of 50 newspapers/newsblogs from different Eastern and Western European countries that specifically identify a social problem facing the Roma in Europe during the years of 2005 through 2015. With few exceptions in Greek, my own native language, all publications were written in English for consistency of analysis with respect to my language and linguistic competencies. Initially, the data were analyzed through an open coding that identified recurring patterns or themes. The data were then reorganized into functional and grammatical categories pertaining to the representations and attributes related to Roma children and triangulated with the kind of argumentation structures they employed.

\section{Findings}

The thematic analysis generated domains in which Roma children and their childhoods were at stake: 1) societal and marginalization; 2) educational failure; and 3 ) child labour and child abuse. Two topics of argumentation emerged from the analysis. The first argues that nation states discriminate against the Roma children and their families and this is the reason why they are doing so poorly on social indicators. The second argues that Roma families' inability or resistance to assimilate is the cause of their children's deprived childhood. Both lines of argumentation construct an implausible childhood that Western human rights organizations have intervened upon. Their discursive intervention is the focus of this study.

\section{Marginalization and the Dangerous Childhoods of Roma Children}

A predominant theme across the texts examined in this study is that Roma children are socially marginalized and experience dangerous childhoods. The discourse is largely constructed through enthymemic rhetorical devices, which present syllogisms with implied premises: 1) that there is a specific kind of "adult" life for which to prepare; and 2) that governments are aware and capable of protecting Roma children. Both premises are logical fallacies. Consider, for example, UNICEF's position on Roma children's "protection." UNICEF identifies Roma children as more likely to "suffer from discrimination, exploitation, violence, and neglect" (UNICEF, n.d.-b para 1). Based upon a predetermined register from within the dominant United Nations cultural perspective, they go on to argue: "their childhood fails to prepare them for adult life". Under the Convention on the Rights of the Child, governments are obliged to protect all children and are accountable for failure to do so (UNICEF, n.d.-b, para. 3). The question that readers must ask UNICEF is protection from whom? Nowhere on this webpage does UNICEF identify the victimizers of Roma children or question their own assumptions and cultural privileges.

Nonetheless, given the types of suffering identified, the readers can infer that both private and public social institutions may be involved in "discrimination;" however, "exploitation," "violence," and "neglect" are likely suffered predominantly at the hand of Roma parents and community members. UNICEF then goes on to argue that this suffering can be perpetuated because "many Roma children are born into families living in poverty, which puts them at risk of child labour and unsafe working environments and other risks associated with family disempowerment" (UNICEF, n.d.-b, para. 3). By implicating Roma parents and guardians as threats to their children's lives, UNICEF constructs the Roma child as victim (and product) of failed parenting and social inequity. Their failed parent is, in part, a result of their inability to keep their children out of poverty. According to the UNICEF, any society that does not protect "its most marginalised children denies them the chance to reach their potential and undermines its own chance to develop" (UNICEF, n.d. -b, para. 3). Hence, UNICEF presents us with the proposition that Roma children can never be fully realized adults because victimization stunts them from developing interpersonal, cultural, and economic tools during their childhoods.

Yet despite structural inequalities that have resulted in poverty, Roma and traveller cultures have persisted and survived, and the children therein have developed into adults. And, what is more, many Roma see no need for government intervention or "protection." Consider what traveller and Vice Chair of the UK's Gypsy Council, Candy Sheridan, tells the Office of the High Commission after the Irish government evicted some 300 "Gypsies" from land they owned:

\footnotetext{
"I am proud of our Traveller traditions, but of course change is coming to the Travellers, too," says Candy. "We don't want to live permanently apart from other people. We want our children and grandchildren to have an education, to study, to have opportunities in life. But this development must come from within the Traveller community, from our own choices, not as a result of being forcibly dispersed and displaced. And we should not be forced to renounce our identity." (Office of the High Commission for Human Rights, 2013a, para. 12)
}

Ms. Sheridan postulates that Roma people must develop their own cultural understandings, choices, and values to combat governments paternalistically forcing them to live in particular ways in order to fill hegemonic and dominant culture goals. Not once in the United Nations Human Rights page did the Office of the High Commissioner discuss that Ireland and the Irish gov- 
ernment officials may be acting with imperialistic and paternalistic intentions by seeking to evict traveller people from land they purchased. Critical theorist Carl Schmitt argues, "land-appropriation precedes the order that follows from it. It constitutes the original spatial order, the source of all further concrete order and all further law" (2003, p. 75). Hence, through the appropriation of land, the Irish government invokes an order and law that serves to marginalize Roma families.

In addition to the using enthymic rhetorical devices, almost all the texts analyzed used the passive voice to obscure the perpetrator of Roma oppression. Consider the following excerpts, which I identified as victimizing the Roma children without naming the victimizing agent. Instead, the agentless subject of the sentences remains "the Roma." I italicize and the passive voice to demonstrate how both the United Nations reports and the news media construct the victimizers as disembodied entities:

"In the last three years, more than 2,500 Roma from Kosovo have been forced to leave Germany, including people and families that lived in Germany for years. DW reports on the deportation of a family back to Kosovo." (Cani, 2013, para. 1)

“Roma and Travellers are among Europe's most excluded groups, facing widespread discrimination (and often segregation) in many areas of life including housing, education, employment and health." (United Nations Working Group on Roma, n.d., para. 1)

“The Ligue des Droits de I'Homme (LDH) together with the European Roma Rights Centre (ERRC) report that a record number of over 13,000 persons have been subjected to forced evictions in the first nine months of 2013. During the evictions, the meagre property of Roma migrants is often destroyed, forcing them to re-start from scratch. Children's school attendance is interrupted as families have to move and no housing alternatives are provided. Sometimes they are driven from one municipality to another, which the Ombudsman has described as an example of "forced nomadism." (Working for a more inclusive policy towards migrant Roma in France, 2013, para. 5)

In just these three excerpts containing 6 sentences, the authors use the passive voice, "have been forced," "are...excluded," "have been subjected to forced," "is often destroyed," "is interrupted," "are driven." In the case of these passive sentences, the actors of force, exclusion, subjugation, destruction, interruption and driving away are masked. In truth, the subjects are the governments of Ireland, European countries, and France, respectively. By not naming them, the news and human rights organizations allow for the governments to be invisible victimizers and violators of human rights. Conversely, the authors construct the Ro- ma families with the language of victimization, without agency, and absent of resistance. They "fac[e] deportation" and "have" to move. By constructing the Roma children and families in this way, they remain the passive recipients of unquestioned authority.

The media does not reveal the identities of the victimizers even when they are tried and convicted of capital murder. One case is the 2009 murder of a Roma father and young son by "Right Wing Extremists" in Hungary (Verseck, 2014, para. 4). In naming them as "extremists," the journalists also distanced these individuals from mainstream dominant culture, thus exonerating a society wherein a discriminatory zeitgeist acts against the Roma people. The "Right Wing Extremists" are sometimes referred to only as the plural pronoun "they," further disassociating their act from a name or identity in its anonymity. The passive verbs associated with the Right Wing Extremists ("were caught," "were sentenced," "were convicted,") only point to their punishment. The implied actors of these verbs are the government officials who prosecuted them. The killings, then, are detached from the agents of violence. The only adjective attached to them is "fanatical," which is already a synonym for extreme and still does not reveal the name of the so-called "extremists." Masking their names also masks their ethnicity and national origin. The article, however, does provide the names of the victims' family members and the fact that they are Roma. In so doing, Roma is constructed as the only relevant or non-normative ethnic category.

Rather than explain the origins and wrong doings of the "Right Wing Extremists, the focus is on the financial situation of those murdered-"Erzsebet Csorba and her family," are linked to the descriptor "poor," as though their poverty is a logical explanation for their murder. The only mention of the murdered child was a summarized memory from the grandmother: "And she remembers how she was holding her grandson, little Robi, in her arms. He was just four years old, and he was dead, riddled with shot pellets" (Verseck, 2014, para 3). There was no discussion of why the murderers would kill an innocent child. Instead, the particular sentence, "Erzsebet Csorba and her family are poor," (Verseck, 2014, caption) distracts from the topic of murder promised in the title. While the topic is the serial murders of Roma people in Hungary, the article states that "Roma families" live in "humble" houses on the "outskirts" of town-a "remote village." Csorba's home, specifically, is the "nearest to the forest"-making it the most "outskirted" of all the homes. This emphasis not only distracts from the crime at hand and any social factors contributing to it, but also allows for the Csorba family, the pitied victims, to be depicted as individuals literally residing at the margins of Hungarian society. Such a depiction implicitly frames the Roma as abject beings in Hungary; as the "not-1" against which Hungarians can construct their national identity. 
In this same article, the author names liberal politician, Jozsef Gulyas. However, it is neither for any abrogation of responsibility nor for discriminatory practices but rather for his advocacy and care giving: "Gulyas takes care of the survivors and families of victims. He continually collects donations from friends" (Verseck, 2014, para. 12). It is not, therefore, that European journalists and human rights organization never use the active voice, but that the active voice is typically used to emphasize either victims or their champions rather than their oppressors.

Similar to the use of the collective noun, "the right wing extremists," "the police" is a noun category identified as culpable. In another article discussing Hungary, László Siroki, the coordinator of the Hungarian Civil Liberties Union, is quoted saying:

"Roma also suffer harassment from the police-and that challenging such practices forms the bulk of his human rights work in the Cserehát region. "Roma often get absurd fines that no one else would get," says Siroki. "They get fined for children playing in a park, for collecting mushrooms in the forest, or even for technical deficiencies of their bicycles." (Office of the High Commission for Human Rights, 2013b, para. 4)

As in the other excerpts, Roma are framed as people who suffer harassment and are victimized through racial profiling and criminalization of culture. This reverence to the police is one of the few times that the victimizers were identified, even if they were simply a collective noun, such as "the police." However, none of the police officers that engaged in the "harassment" were named, and the resulting illocutionary message is that the Police and the Roma are at odds with one another. Nonetheless, the Police have authority, trust, and legitimacy by law, while the Roma do not have any legitimacy in this discourse. This disparity, especially in the context of crime and policing, again characterizes Romani people as criminal and other.

\section{Roma Children Constructed as the Product of Failed Families}

Some European media also criticize Roma children and their families. Consider the argumentation structure of the following excerpt:

That fear is now erupting into violence. Earlier this week Roma camps near Naples had to be evacuated after local people torched the shacks, angered by reports that a teenage Roma girl tried to kidnap an Italian baby. Her arrest at the weekend sparked days of bitter protests, and on Wednesday night vigilante groups in the Naples suburb of Ponticelli chased Roma out of two squatter camps by throwing Molotov cocktails into their huts. (Spiegel, 2008, para.3).
The narrative of the Italian raids on Roma camps is framed as a justified response to the alleged criminal behavior of a Roma girl. The article represents the "local people" as "angered" by the kidnapping, and therefore explains and rationalizes the torching of Roma housing (shacks). It does not, for example, explain how Roma people were terrorized or threatened by the torching, which is presumably as illegal as the alleged kidnapping. The criminal behavior explains the "bitter protests" against the Roma people. Thus, the narrative again repeats the frame that violence toward the Roma people was incited by Roma behavior. For example, the bitter protests gave rise to "vigilante groups" who "chased out Roma out of two squatter camps by throwing Molotov Cocktails into their huts." By identifying "local people" and "vigilante groups" as collective bodies seeking justice, and by identifying the Roma as "kidnappers" and "squatters," the illocutionary force of the piece constructs Roma children and their families as abject beings who readily embrace criminal behaviors.

The lawlessness of the Roma people is further reinforced two paragraphs later, by declaring them as "immigrants without proper papers:"

On Thursday police officers carried out raids on a Roma camp in Rome and detained over 50 Bosnian and Romanian immigrants without proper papers. Speaking at the same ceremony as Maroni on Friday Italian Police Chief Antonio Manganelli said that "only by blocking the entry into Italy of people who refuse to integrate, people who import crime, will we be able to help ease the fear that has crept across swathes of our country. (Spiegel, 2008, para. 5)

The article constructs the dominant group-Italian people-as agents aligned with the state against Roma from Eastern Europe who are therefore enlisted to "help" report crimes that can result in the deportation of the Roma, who "refuse to integrate." The illocutionary force of the article piece is that Roma are culturally criminal, abject beings and their unlawful presence in Italy is not only a threat to national security, but also a threat to Italian culture, since the Roma "refuse to integrate." This assimilationist ideology justifies the home torching as a matter of national unity. Their lack of ability to assimilate fashions Roma Childhood as a failed project in socialization and the result of faulty and deficient child rearing.

The framing of Roma people as undocumented immigrants constructs a legal basis for their removal and deportation. Based on immigration law, Roma children can be sent "back" to their parent's original country:

Adnan, along with his 12-year-old brother Senjur and mother Vesvije, were deported from Germany back to Kosovo about a month ago. Vesvije, a 45year-old mother, described how the police showed 
up at their house at 5 a.m., while she was sleeping due to the medications she has to take. There were a lot of people: immigration officers, police, a doctor. And they said, "Pack your things, you're going to Kosovo." They were immediately taken to Kosovo, to the newly rebuilt "Roma Mahala" in Mitrovica, northern Kosovo (Cani, 2013).

The news media representation of their presence in Germany as unlawful justifies their dislocation and forced return to Kosovo. The inclusion of details about the mother taking medication calls her character and fitness as a parent into question and distracts from the fact that the two children were forced out of their home one morning. The article's framing of the family as law-breaking diminishes the innocence of the children and constructs them as threats to law and order.

In addition to constructing Roma families as a safety threat, a public concern about Roma child socialization within families has to do with early marriages. In 2015 United Nation Population Fund, Executive Director, Dr. Babatunde, argues, "the decision to marry should be a freely made, informed decision that is taken without fear, coercion, or undue pressure. It is an adult decision and a decision that should be made, when ready, as an adult" (Martsenyuk, 2015 p. 1). The report recommends that the Ukrainian government consider the Roma Specific Recommendations, especially by "provid[ing] information to Roma community members (especially young women and men) on sexual and reproductive health and on health consequences of child marriage" (Martsenyuk, 2015, p. 2). In the same article, the UNPF recommends that Ukrainian education programs educate these young women on "sexuality, reproductive choices, and family planning" (Martsenyuk, 2015, p. 7). Such programs are reminiscent of eugenic feminist movements, which under the guise of female empowerment, target marginalized communities for population control (Ziegler, 2008).

The argumentation on Roma girls is that their early entry into motherhood is both an immoral and irresponsible cultural practice. Consider the following news article critiquing young Roma mothers:

She is called Nicoletta and, undoubtedly, is as delightful as any healthy newborn baby. But her birth 10 days ago in the southern Spanish city of Jerez has provoked a storm-because her mother is just 10 years old.

What has shocked the rest of the world, however, is described as a happy event by the family. "My daughter is well, as is the little girl-who is very fine and pretty. She is very happy with her daughter," the baby's Romanian grandmother, Olimpia, told Spanish journalists. This is not a drama, it is a cause for happiness. At this age we marry in Romania. It is normal amongst we Gypsies (Tremlett, 2010, para. 1-2)

The article's main rhetorical device is to contrast Roma cultural constructions of childbirth with those of mainstream Spain. The reader's attention on the "delightful" and "healthy" baby is disrupted by the coordinated conjunction "but," which stands in contrast to the "just 10 years old" mother. Similarly, the shock of "the rest of the world" stands in contrast with the Romanian grandmother's claim that "it is a cause for happiness...It is normal amongst we Gypsies." The apparent cultural clash between what is "normal" in Roma culture and what is normal in Spanish culture is constructed as a "storm" by discursively framing the Roma girl, her family, and all Roma as deviants. The Roma girl, framed as an abject being, stands in sharp contrast to normal Spanish girls, whose childhood is preserved by their culture, which protects them against parental and spousal responsibilities.

Similarly an 11-year-old Roma girl residing in Crete becomes the youngest girl to give birth on the island:

It is not the first time that a minor girl gives birth to a baby, but it is certainly a Greek first. Sunday evening, an 11-year-old girl visited a hospital in Irakleio, Crete, complaining about acute pain in the belly. Much to the surprise of the hospital personnel the minor was not suffering from some bad food. The girl was 7 months pregnant. The doctors took the baby with a Caesarean section as it was impossible for the girl to deliver the baby with a natural birth procedure due to her young age....According to local media, the girl went to a public hospital on Sunday evening in the company of a woman who most likely was not her mother. Both the girl and the woman are Roma. Some media report that the minor mother was exactly 11 years and 5 months old. (UPD Crete, 2014, para. 1).

Mention of the hospital personnel's surprise serves to differentiate between Greek teenage mothers and the 11-year-old Roma girl, whose young age made her "a Greek first." While the article does not elaborate as to whether the girl knew she was pregnant, it constructs her as unaware of the cause for "belly" pain. The implication is that she is far too young to know how to take care of herself, let alone a baby. However, Roma people are not as atomistic and rarely live by themselves with a baby. There are typically many family members surrounding children. Additionally, the conjecture that the woman with her was not likely her mother, implies that either she is neglected, kidnapped, or possibly trafficked-all accusations typically levied at Roma families. Sometime after the initial report, another Greek news blog reported that the girl had been having an "affair" with a 14 year old boy who soon disappeared after being notified of the pregnancy (Crete: 
Tha eksetasti, 2014, para. 4). By including this additional information and framing the girl's pregnancy as the result of an "affair," the report creates an image of her as a promiscuous, yet naïve girl-a confounding contradiction. How can she be both a child and have an "affair"? It is clear that her status as a child is incompatible with the dominant culture's idea of childhood.

In a Russian news report, Bashtam Gorbunenko, a 12-year-old girl, is constructed as emerging out of a line of women who do little else than breastfeed children, as though it were culturally hereditary:

Well, it happened by accident, so I had to give birth to my child," says Bashtam Gorbunenko as she shrugs her shoulders. Bashtam lives in the village of Komsomolsky, in the Volgograd region. She turned 12 in February. (Grachev, 2006, para. 1)

These days Bashtam is breast-feeding two babies since her first son is just one year old. Despite being a teenager herself, Bashtam has plenty of milk in her mammary glands. The circumstance is apparently running in the family-Pavlina, Bashtam's mother, used to breast-feed her babies until they turned 3-4 years old. (Grachev, 2006, para. 7)

The focus on Bashtam's mammary glands and the "plenty" of milk that she has, "despite" being a teenager, implies that there the Roma girl is biologically abnormal. By emphasizing that she is breastfeeding two babies at 12 years, the article constructs her as an irresponsible mother, who nonchalantly "shrugs" off the fact that gave birth for a second time in a year's time, and will be dependent on others to take care of her, thus reproducing a cycle of dependency that threatens Russian society. Implied in this analysis is a critique of Roma reproduction, a desire to stop it through thanatopolitics (Agamben, 2009) shrouded in a discourse of the sanctity of childhood.

\section{Roma Children "At Risk" of Educational Failure}

"The mental age of an average adult Gypsy is thought to be about that of a child of 10" said the 1959 edition of the Encyclopedia Britannica, 14 years after the end of the Nazi genocide of Romany Gypsies (Le Bas, 2014, para. 1). It seems that little has changed since 1959 when it comes to the public attitudes toward the Romani people. The education of Roma children is both a civil and human rights matter, as framed by the human rights organizations, such as Amnesty International, UNICEF, and the United Nations human rights divisions. According to these organizations, schools in both Eastern and Western Europe operate on a deficit model with respect to Roma people and have been negligent and victimizing of Roma people by refusing Roma children entry, segregating them into separate and sub- standard schools, or by placing them in Special Education programs, where they receive only the most remedial education. Watchdog organizations, such as the Czech Schools Inspectorate "expose" the schools for their discriminatory practices. The organizations, however, never name the real decision-makers in schools and do not identify the apparatus for segregative practices; instead, they too employ the passive voice, along with nominalized verbs to mitigate and distribute responsibility. The italicized passive voice verbs, nominalized verbs, and gerunds illustrate the discursive problem:

A 2013 survey by the Czech Schools Inspectorate (the national body responsible for ensuring schools comply with national legislation) exposed the disproportionately high number of Romani children in schools for pupils with "mild mental disabilities." The monitoring of 483 schools with five or more pupils with this diagnosis found that a staggering $28.2 \%$ of them were Roma. However, Roma make up less than three percent of the total population. The Czech Ombudsperson (responsible for monitoring and ensuring compliance with anti-discrimination legislation) found this to be discriminatory in 2012....The prospects for Romani children that do make it to "mainstream" education are not much better. Many are segregated into schools and classes with lower educational standards. In 2014, Amnesty International has continued to collect evidence of Roma-only mainstream schools in which the educational programmes followed differed very little from those of schools for pupils with "mild mental disabilities'" (Amnesty International, 2014, para. 7-8).

Many Roma children end up in institutions and special schools, which leave them isolated from family and community and at risk of abuse. The overrepresentation of Roma children in institutions is a direct consequence of wider exclusion from society, lack of appropriate support to families to prevent separation, and a direct consequence of a system of identification of children with disabilities based on "defectology" approaches which tend to classify many Roma children as in need of "special education" on unsubstantiated grounds. (UNICEF, n.d.-b., para. 2)

Roma children in all countries across Europe are at risk of experiencing the systematic violation of their rights reflected in severe poverty and marginalisation, discrimination and the denial of equal access to services and of equal opportunities in society. Policies are rarely 'in the best interest' of the Roma child and the voices of Roma children and young people are often not taken into account. (UNICEF, n.d.-a, para. 1) 
With regards to education, efforts are also being made to achieve the full integration of Roma children in school. After the closing of the segregated primary school in the excluded Romani slum of Schinoasa in 2010, Roma children went to study in an integrated school with children from the majority population in the town of Tibirica, $7 \mathrm{~km}$ away from the Romani settlement of Schinoasa. A minibus service was put in place to allow children from Schinoasa go to school since there was no regular public or private transportation between the Romani settlement and Tibirica. "When Roma children from Schinoasa had to walk seven kilometres to Tibirica and back every day, their attendance was very poor. Roma parents were complaining of security because in winter it gets dark very soon. It was necessary to provide transport for the children", Claude Cahn explains after visiting the Romani settlement in Schinoasa. (Office of the High Commissioner for Human Rights, 2013c, para. 5).

The passive voice verbs, "are segregated," "are at risk of," and "are often not taken into account," obscure the unnamed agent of the sentence, making the Roma children the subjects of the sentences, thereby protecting the interests of the schools and drawing the reader's attention to the social problem - "the Roma children." Similarly, the nominalized verbs of "over exclusion," "separation," marginalization," "discrimination," and "denial" also function to focus the reader's attention to the result of the practices rather than on the root cause-the government-appointed school officials and the evaluative tools of "defectology" they employ. Similarly, the use of gerunds, as in "the closing" focuses the reader's attention to the act of closing, conveniently deleting the entity that made the decision to close the Roma schools. There is no doubt that the human rights organizations have identified one of Europe's most pressing civil rights issues-the exclusion of Roma children from compulsory public schooling. Nonetheless, the obscuring nature of the discursive grammatical choices that the human rights organizations employ provides protection for those who continue to victimize deny Roma children opportunities for full democratic participation.

Roma children are marginalized, given fewer resources, and constructed as having lower intelligencebut we never find out exactly who does this and how. Roma children are victims of state educational neglect and the organizations' discursive solution is to point out the legal violations - but we never know who exactly violates the law. The discourse attacking "schools," does not take into account the populace in so-called democracies that fund and operate them. Lacking in the analysis is the identification of two operant populist ideologies. First the persistent ideology proposed back in 1959 by the Encyclopedia Britannica, that Romani people are intellectually inferior as a cultural group. While such thinking may seem preposterous in this day and age, the ideology is, unfortunately, very much alive and well. The use of cultural- and classbiased IQ tests that cannot control for poverty and cultural differences continue to be a measure of superiority and inferiority. Cvorovic (2014) argues that across different countries Roma people have an average IQ of 70 , or roughly two standard deviations below the norm. Second, that nation states do not see it as their responsibility to educate Romani children. Even though economists have argued that improving education for Roma children will benefit European economies (Kertesi \& Kezdig, 2006), Europeans continue to construct Roma people as freeloaders. Consider Robin Page's column in the UK's Daily Telegram:

The "pikeys" and "didicoys" are the problem, those caravan dwellers who don't travel, pay no rent, drive around with no vehicle license or car insurance, and who know as much about income tax as I do about algebra. They spend their time cruising around pinching whatever they can lay their hands on. (Page, 2011a, para. 9)

In another column, the very next day, Page quotes a woman protesting Roma public housing: "I have lived here for $\mathbf{2 8}$ years and it's a sleepy village and it's family orientated. Everybody has got to have a place to live but if they could only live in a civilised manner and pay taxes like everyone else in the village" (Page, 2011b, para. 24). The discrimination operant in the schools is an expression of the larger discourse of disdain against the Roma people, conceptualizing them as intellectually inferior and uncivilized. The children of these allegedly inferior people, limited by intellectual capacity, do not deserve to partake in public services, because they don't pay taxes "like everyone else." It is the fact that they are not like everyone else that makes their humanity problematic in Ms. Page's eyes.

Despite the human rights discourse of Roma children as victims of cultural and racial discrimination by dominant citizens of European countries, they are also constructed as culpable and partially responsible for their own educational disenfranchisement. Their disenfranchisement from school is attributed to their actions through the use of active verbs. Consider the following excerpts with verbs in italics:

Despite efforts to expand and improve education for children in the Roma community, the largest ethnic minority in Europe, an estimated 50 percent fail to complete primary education, according to a report on early childhood education unveiled today at a conference co-organized by the United Nations. (Half of Roma children drop out of primary school, 2010, para. 2) 
Some children also leave school and start work earlier than others because of their origin or identity.... southeast Europe, it is children from the Roma minority. In each case, a combination of supply and demand factors are at work: the communities concerned feel that the school system was not designed for them and consider it normal for children to abandon school early and start work. (Balaguer, 2005, p. 12)

Those who are in school often drop out early to seek work. The underlying problem is one of prejudice and discrimination in local social services and the community, rather than a lack of infrastructure or services. (Balaguer 2005, p. 14)

In contrast to the previous excerpts where subjects of the sentences masked the victimizers of Roma children through the use of passive verb constructions, the same human rights organizations use active verbs to shift the blame of failure and risk onto the Roma children and families. These children "fail" school, "leave" school, "abandon" school, and "drop out." They are both the agents and the subjects of their discursive failure.

Their failure is vilified as a cultural imperative. Consider this ridiculing feature story on very young mother, "Bashtam," in a Russian newspaper below:

Bashtam does not sing lullabies to her children, and she does not tell them any fairy tales. "They're too small, they won't make out anything, anyway," says she. She is not going to read them any books either. Bashtam and her husband never went to school, she can't read, neither can he. But the young mother believes the ability to read and write does not matter much. She says raising her children strong and healthy is the most important thing. The Gorbunenko seniors share her views on literacy. "The woman is made for managing her household! You don't have to be able to read or write to be a good housewife. I can't read or write but I brought up four children, so what? Bashtam is good at taking care of the kitchen garden. I don't see any problem here," says Natalya, the mother of Mikhail. The young parents don't seem to see any problems related to a lack of money either. The Gypsies do odd jobs sometimes, and the money is barely enough to make both ends meet. "We, the adults, do need money to buy some nice clothes or a yummy thing. What the hell do children need money for? They suck on the teat all right. And we have a good stock of children's clothes. These rompers have been worn by my younger brothers and sisters, I wore them too in my time," says Bashtam.

She does not look so certain this time when asked about her plans for the future. "You know, you never know. Maybe I'll be in a family way again," says she with a shrug of her shoulders. (Grachev, 2006, para. 8-9)

Bashtam's distrust of and divestment from education and literacy and subscription to traditional patriarchal hegemony reiterates and affirms the dominant stereotype of Roma women as presentist, undereducated, unrealistic, lacking ambition, and lacking intelligence. Her project of childhood is a failure, as she demonstrates that she will not be ready to participate as a fully actualized adult by the normative, dominant hegemonic standards of adulthood. The article uses this one case to illustrate all of the cultural critiques that are central to the negative public discourse on Roma people and which hold the Roma people fully responsible for their lot in life.

\section{Child Labour and the Threat against Childhood}

Child labour is perhaps one of the most controversial topics with respect to Roma child rearing. Labour and the responsibility to earn money seem to be distinguishing features between adulthood and childhood in countries subscribing to the United Nations child labour policies. However, Roma people are a landless nation and do not necessarily subscribe to the edicts put forth by the United Nations on child labour. The reasons are complex. On the one hand, some Roma are amongst the cultural minority groups in Europe and need as much family income as possible to ensure the stability of the family. Their survival is sometimes on the labour of all family members, including that of the children. On the other hand, under certain conditions, child labour is considered a violation of child rights according to Article 32 the 1990 Convention of the Rights of the Child:

States Parties recognize the right of the child to be protected from economic exploitation and from performing any work that is likely to be hazardous or to interfere with the child's education, or to be harmful to the child's health or physical, mental, spiritual, moral or social development. (United Nations, 1990, Article 32)

Consequently, Roma families run the risk of being accused of child abuse by human rights organizations, like UNICEF, that have acted as watchdogs documenting child labour violations against Roma Children. Consider the representation of Roma children by UNICEF:

In some communities, employing children full time is the norm, and is seen as positive and beneficial for both the employer and the child concerned. In the small Roma community in Northern Ireland, for example, boys often start their working life at 11 or 12 , once they have been confirmed. They usually 
help their fathers in their business, which might be tarmacking roads or cleaning windows with power hoses. Whatever the discrimination and exclusion felt by some communities, every child in the UK has the right to go to school, a right set out in law. The UN Convention on the Rights of the Child makes it clear that all children have the right to develop to the fullest, a right infringed if a child works full time at the expense of their education..... In some European countries, it is predominantly minority groups, such as Roma and recent immigrants, whose children start work while still below the minimum legal age for employment. However, some industries involve more child workers than others. In Portugal, some 47,000 school-age children were reported to be working instead of attending school, many of them making shoes.18 The Portuguese government has made efforts for more than a decade to end this practice. Fewer children are employed in workshops or factories than in the past, but there has been a corresponding increase in the number of children working in their own homes. (Balaguer, 2005, p. 32)

UNICEF argues that, independent of discrimination, Roma boys in Ireland and Roma children in Portugal have the right to go to school. In this way, Roma children are constructed as both the victims of societal exclusion and the victims of their parents, who remove them from school so that they can work. This perspective, however, neglects the narratives of the Roma children themselves. Irish Roma boys, for example, must often reconcile their "rights" as children according to the law with their families' needs. The "discrimination" and "exclusion" that Roma people feel is realized through fewer opportunities to make money and provide income for their families. Without the help of child labour, Roma families inevitably lose muchneeded income, but if they do not send their children to school, they are in violation of the law. Thus, the Roma boys' victimization renders their childhood inadequate to prepare them for the Western conception of their "fullest potential," yet their fullest potential cannot be possible if they are starving and homeless.

The non-profit reportage and news reports on child labour by Roma children construct them as vulnerable children regularly exploited by both their culture and their parents. Many, for example, are enslaved into forced begging, pickpocketing, commercial sexual exploitation, or fraudulent marriage for domestic service. To illustrate, consider the language-particularly the accusations levied against the parents, which I have italicized -in a report by the Bureau of International Labour Affairs documenting the worst forms of child labour:

Most children in [Bosnia and Herzegovina] who are found in the worst forms of child labor are Roma.
Roma children are sometimes used by their parents or guardians to beg. Organized groups also exist that traffic ethnic Roma children and force them to beg. In addition, the Roma custom of paid and arranged marriages between families has resulted in the exploitation of Roma girls as domestic servants. There is a lack of data on the extent and nature of the worst forms of child labor in the country, including the use of children in pickpocketing and commercial sexual exploitation. Many Roma children do not attend school, which makes them vulnerable to the worst forms of child labor. (Bureau of International Labor Affairs, 2014, p. 98)

Some children in Macedonia engage in begging at the behest of their parents or other family members, while other children are forced into begging. The majority of children involved in work on the streets, including begging, are of the Roma ethnicity. Girls, particularly Roma girls, are trafficked for fraudulent marriages, which may result in them being sexually exploited or forced into domestic service. Girls in Eastern and Central Macedonia have been identified as being at particularly high risk for trafficking (Bureau of International Labor Affairs, 2014, p. 463)

The media in Europe also regularly reports on Roma children being exploited and victimized. The news stories compiled for this paper report that throughout the European Union, young Roma children are forced to beg (Bagnall, 2009; Wright \& Eccles, 2010, para. 1-2) and steal (Bagnall, 2009; Ghosh, 2012; Wright \& Eccles, 2010, para. 1-2) and are thereafter punished with harsh beatings if they do not return home with a sufficient amount of good and money (Bagnall, 2009; Miller, 2013). Additionally, there are reports of Roma children being sexually trafficked (Wright \& Eccles, 2010, para. 1-2).

Unlike the agentless victimization in the educational discourse, the discourse of child labour violations clearly identifies the victimizers: the parents, fellow Romani, and the Roma culture. Their parents force them to beg, steal, engage in sexual exploitative acts, and enter into fraudulent marriages for slavery and servitude. Their childhoods are sacrificed for money by their caregivers, and therefore, their culture renders them incapable of their own self-actualization and participation in democracies. Their childhoods are, thus, dangerous and depart from the normative childhood set forth by the UN Convention of the Rights of the Child.

\section{Conclusions}

The discourse of care and protection invoked by human rights organizations and the European media present Roma children as the victim of unethical and in- 
humane treatment by their nation-states and communities. However, a close examination of the discourse machinery employed in constructing the Roma childhoods reveals that both the news organizations and the human rights organizations avoid blaming governmental organizations and prefer to discursively construct Roma childhoods as dangerous and devoid of the resources that lead to healthy adulthoods. Their parents, the products of their own failed childhoods, are blamed. The discourse constructed in the last 10 years by media and human rights organization is both the product of and the machinery of hegemony (Gramsci, 1971). Well-meaning organizations such as the UN, UNICEF, and Amnesty Internationals are the unwitting producers of such discourses, which have simultaneously vilified and victimized Roma childhood, entrapping it in a liminality-a non-childhood. More to the point, the discourse of victimization, which calls for direct intervention, constructs the Roma children as abject beings whose impossible and implausible childhoods that keep them from developing into adults who are law abiding, contributing members of European societies. The interventions of organizations, such as the United Nations, reflect Foucault's critique that the state has constructed itself to not only institute legal order within political boundaries, but also to control procedures, techniques, and strategies that control, manage, and regulate populations (Foucault, 2003). The discursive tool of human rights advocacy, with its focus on the societal and familial failures constructing Roma childhoods as problematic, without highlighting the positive and affirming nature of their childhoods, suggests that the Roma can never produce healthy childhoods - only poverty, alienation, and marginalization. Such a discourse also forecloses on the possibility that some Roma communities can and may have developed their own interventions for cases of child abuse and victimization that do not reiterate or reproduce dominant culture fears of Romani cultures but rather reinforces strong and resilient family ties aimed at protecting and acculturating their children without governmental interference.

\section{Acknowledgments}

Thanks to Anastasios Nikolas Angelopoulos and Professor Richard Mora for their editing support.

\section{Conflict of Interests}

The author declares no conflict of interests.

\section{References}

Agamben, G. (2009). What is an apparatus? Stanford, CA: Stanford University Press.

Amnesty International. (2014, September, 9). EU action against Czech Republic for discrimination in schools is a victory for rights justice, and Roma. Retrieved from http://www.amnesty.org/en/news/eu-actionagainst-czech-republic-discrimination-schoolsvictory-rights-justice-and-roma-2014-09

Bagnall, S. (2009, September 2). How Gypsy gangs use child thieves. BBC News. Retrieved from http://news.bbc.co.uk/2/hi/8226580.stm

Balaguer, A. (2005). End child exploitation: Child labour today. New York: UNICEF.

Barkham, P. (2005, March 10). Gypsy groups report the sun to the police. The Guardian. Retrieved from http://www.theguardian.com/media/2005/mar/10 /pressandpublishing.localgovernment

BBC. (2010, July 29). France to shut illegal Roma camps and deport migrants. British Broadcasting Corporation. Retrieved from http://www.bbc.co.uk/news/ world-europe-10798440

BBC. (2015, January 4). Roma baby refused burial in France. British Broadcasting Corporation. Retrieved from http://www.bbc.com/news/world-europe30670371

Bureau of International Labor Affairs. (2014). 2013 Findings on the worst forms of child labor. Washington, DC: United States Department of Labor.

Cani, B. (2013, March 30). Deported Roma face tough time in Kosovo. Deutsche Welle. Retrieved from:http://www.dw.com/en/deported-roma-facetough-times-in-kosovo/a-16710238

Christianakis, M. (2010). Lessons for life: Roma children, communal practices and the global marketplace. Perspectives on Urban Education, 7(2), 11-18.

Collins, P. H. (2008). Black feminist thought. Knowledge, consciousness, and the politics of empowerment. New York, NY: Routledge.

Cozma, T., Cucos, C, \& Momanu, M. (2000). The education of Roma children in Romania: Description, difficulties, solutions. Intercultural Education, 11(3), 281-288.

Crete: Tha eksetasti apo psixiatro to koritsaki pou egine mitera. (2014, December 30). Zougla. Retrieved from http://www.zougla.gr/greece/article/kriti-8aeksetasti-apo-psixiatro-to-koritsaki-pou-eginemitera

Cvorovic, J. (2014). The Roma: A Balkan underclass. UK, London: Ulster Institute for Social Research.

Dewsbury, R. (2012, April 12). Swiss magazine defends picture of Roma boy holding toy gun after complaints from gypsies that it's like 'Nazi propaganda'. Daily Mail. Retrieved from http://www.dailymail. co.uk/news/article-2128756/Weltwoche-Romaarticle-Swiss-magazine-defends-picture-boyholding-toy-gun.html.

Fairclough, N. (2013). Critical discourse analysis: The critical study of language. New York, NY: Routledge.

Fairclough, N., \& Wodack, R. (1997). Critical discourse analysis. In T. A. van Dijk (Ed.), Discourse studies. A 
multidisciplinary introduction, Vol. 2. Discourse as social interaction (pp. 258-284). London: Sage.

Foucault, M. (1977). Discipline and Punish: The birth of the prison. New York, NY: Vintage Books.

Foucault, M. (2003). Society must be defended: Lectures at the College de France, 1975-76. New York, NY:Picador.

Frisman, E., Rácz, O., Petrovicová, J., Slávik, J., \& Cimboláková, I. (2015). Scald burns in children. An analysis with special attention to the Roma ethnic group in East Slovakia. International Journal of Clinical Medicine, 6(01), 44.

Ghosh, P. (2012, January 6). France gets tough on Roma (gypsy) immigrants. International Business Times. Retrieved from http://www.ibtimes.com/ france-gets-tough-roma-gypsy-immigrants-392002

Grachev, G. (2006, September 23). 12-year-old Gypsy girl gives birth to another baby. Pravda. Retrieved from http://english.pravda.ru/society/stories/2309-2006/84595-gypsy-0/\#

Gramsci, A. (1971). Selections for the prison notebooks of Antonio Gramsci. New York, NY: International Publishers.

Hajloff, S., \& McKee, J. (2000). The health of the Roma people: a review of the published literature. Journal of Epidemiol Community Health, 54(1), 864-869.

Half of Roma children drop out of primary school, UNbacked report finds. (2010, September 27). Retrieved from http://www.un.org/apps/news/story. asp?NewsID=36207\#.VOAdoLDF-hw

Halliday, M. (1985). An introduction to functional grammar. London: Edward Arnold.

Hardt, M. \& Negri, A. (2001). Empire. Cambridge, MA: Harvard University Press.

Hooper, J. (2008, July 20). Gypsy girls' corpses on beach in Italy fail to put off sunbathers. The Guardian. Retrieved from http://www.theguardian.com/world/ 2008/jul/21/italy.race

Járóka, L. (2007). Roma education on the agenda of the European Union. European Education, 39(1), 81-87.

Kézdi, G., \& Kertesi, G. (2006). Expected long-term budgetary benefits to roma education in Hungary. Budapest, HU: Institute of Economics, Hungarian Academy of Sciences.

Kevorkyan, A., Teoharov, P., Lernout, T., Petrova, N., Raycheva, R., Ivanov, I., \& Kojouharova, M. (2015). Prevalence of HBV and HCV among outpatients in the Plovdiv region of Bulgaria, 2010-2011. Journal of medical virology, 87(3), 401-406.

Kyuchokov, H. (2000). Transformative education for (Gypsy) children: an insider's view. Intercultural Education, 11(3), 273-280.

Lave, J. \& Wenger, E. (1991). Situated learning: legitimate peripheral participation. Cambridge, MA: Cambridge University Press.

Lazar, M. M. (2007). Feminist critical discourse analysis: Articulating a feminist discourse praxis 1. Critical
Discourse Studies, 4(2), 141-164.

Lazar, M. M. (2008). Feminist critical discourse analysis: Studies in gender, power, and ideology. New York, NY: Palgrave Macmillan.

Le Bas, D. (2014). Yes, Gypsies lag in education, but the reasons are complex and cultural. The Guardian. Retrieved from http://www.theguardian.com/ commentisfree/2014/jan/22/gypsies-laggingeducation-gypsies-travellers

Lee, E. J., Keyes, K., Bitfoi, A., Mihova, Z., Pez, O., Yoon, E., \& Masfety, V. K. (2014). Mental health disparities between Roma and non-Roma children in Romania and Bulgaria. BMC Psychiatry, 14, 297-299.

Lee, K. W., \& Warren, W. G. (1991). Alternative education lessons from Gypsy thought and practice. British Journal of Education Studies, 9(1), 311-324.

Lesar, I. Čuk, I., \& Peček, M. (2006). How to improve inclusive orientation of Slovenian primary school-the case of Romani and other migrant children of the former Yugoslavia. European Journal of Teacher Education, 29(3), 387-399.

Levinson, M. P. (2005). The role of play in the formation and maintenance of cultural identity: Gypsy children in home and school contexts. Journal of Contemporary Ethnography, 34(5), 499-532.

Lipnická, M. (2014). Opportunities, constraints and prospects of inclusive pre-primary education for children from marginalized Roma communities. The New Educational Review, 38(4), 57-71.

Litosseliti, L. (2016). Gender and language theory and practice. New York, NY: Routledge.

Martinidis, G., Andrei, R., \& Tkadlecova, T. (2014). Challenges faced by Roma women in Europe on education, employment, health and housing-focus on Czech Republic, Romania and Greece. Balkan Social Science Review, 4, 323-351.

Martsenyuk, T. (2015). Child marriage in Ukraine (overview). United Nations Population Fund. Retrieved from

http://www.unfpa.org.ua/files/articles/4/52/Child\% 20Marriage\%20in\%20Ukraine_Overview.pdf

Mellou, K., Sideroglou, T., Papaevangelou, V., Katsiaflaka, A., Bitsolas, N., Verykouki, E.,...\& Hadjichristodoulou, C. (2015). Considerations on the current universal vaccination policy against Hepatitis A in Greece after recent outbreaks. PloS One, 10(1). e0116939.

Miller, D. (2013, November 22). Police smash Roma pickpocketing network involving hundreds of children who are trafficked out of Paris across Europe and Britain. Daily Mail. Retrieved from http://www.dailymail.co.uk/news/article2511769/Police-smash-Roma-pickpocketingnetwork-involving-hundreds-children-traffickedParis-Europe-Britain.html

Neagu, M. (2013). Decoding political discourse: Conceptual metaphors and argumentation. Basingstoke, 
UK: Palgrave Macmillan.

Office of the High Commissioner for Human Rights. (2013a, June 3). Between traditions and exclusion: Struggling for the right to pitch a trailer. United Nations. Retrieved from http://www.ohchr.org/EN/ NewsEvents/Pages/Betweentraditionandexclusion. aspx

Office of the High Commissioner for Human Rights. (2013b, April 25). Empowering Roma in rural Hungary. United Nations. Retrieved from http://www. ohchr.org/EN/NewsEvents/Pages/RomalnHungary. aspx

Office of the High Commissioner for Human Rights. (2013c, April 25). Bringing inclusion to Roma communities in Moldova's rural areas. United Nations. Retrieved from http://www.ohchr.org/EN/News Events/Pages/RomalnMoldova.aspx

O'Higgins, N., \& Ivanov, A. (2006). Education and employment opportunities for the Roma. Comparative Economic Studies, 48(1), 6-19.

Page, R. (2011a, January 29). Sir Elton John, his wealthy neighbours and the fight to keep gipsies out of their village. The Telegraph. Retrieved from http://www.telegraph.co.uk/news/uknews/829029 4/Sir-Elton-John-his-wealthy-neighbours-and-thefight-to-keep-gipsies-out-of-their-village.html

Page, R. (2011b, January 28). Unwelcome visitors. The Telegraph. Retrieved from http://www.telegraph. co.uk/news/earth/earthcomment/country-diary/ 8286440/Country-diary-A-cocktail-of-creosote-andvinegar.html

Schmitt, C. (2003). The Nomos of the Earth in the International Law of the Jus Publicum Europeaeum; New York, NY: Telos.

Smith, H. (2013, October, 23). Maria case exposes extent of child trafficking in crisis-hit Greece. The Guardian. Retrieved from http://www.theguardian. com/world/2013/oct/25/greece-child-traffickingmaria-bulgaria-roma-dna

Spiegel. (2008, May 16). Roma raids: Italy cracks down on illegal immigrants. Spiegel Online International. Retrieved from http://www.spiegel.de/international/ europe/roma-raids-italy-cracks-down-on-illegalimmigrants-a-553753.html

Tremlett, G. (2010, November 5). Too young to be a mother? The Guardian. Retrieved from http://www.theguardian.com/lifeandstyle/2010/no v/05/10-year-old-mother.

Trimikliniotis, N. \& Demetriou, C. (2009). The Cypriot Roma and the failure of education: Antidiscrimination and multiculturalism as a postaccession challenge. In N. Coureas and Andrekos Varnava (Eds.). The minorities of Cyprus: Development patterns and the identity of internal-exclusion (pp. 241-264). Cambridge: Cambridge Scholars Publishing.

Toulmin, S. E. (2003). The uses of argument. Cam- bridge, MA: Cambridge University Press.

UNICEF. (n.d.-a) Roma children-early childhood. Retrieved from http://www.unicef.org/ceecis/early_ childhood_20302.html

UNICEF. (n.d.-b) Roma children-protection. Retrieved from http://www.romachildren.com/?page_id=9

United Nations. (1990). Convention on the rights of the child. Retrieved from http://www2.ohchr.or...ish/ law/crc.htm

United Nations Children's Fund. (2005). All Rights for Children: UNICEF in Central and

Eastern Europe and the Commonwealth of Independent States. United Nations Children's Fund.

United Nations Development Program (UNDP) (2002). Avoiding the dependency trap. Bratislava, Slovakia: UNDP.

United Nations Working Group on Roma. (n.d.). Retrieved from http://www.ohchr.org/EN/Issues/ Minorities/Pages/UnitedNationsRegionalW GonRoma.aspx

UPD Crete. (2014, December 15). Roma girl, 11, gives birth to a baby. Keep Talking Greece. Retrieved from http://www.keeptalkinggreece.com/2014/12/ 15/crete-roma-girl-11-gives-birth-to-a-baby/

van Dijk, T. (2013). Ideology and discourse. In M. Freeden, L. T. Sargeant, \& M. Tower (Eds.), The Oxford handbook of political ideologies (pp. 175-196). Oxford, UK: Oxford University Press.

van Eemeren, F. H., \& Garssen, B. (2012). Some highlights in recent theorizing: An introduction. In F. H. Eemeren \& B. Garssen (Eds.), Topical themes in argumentation theory (pp. 1-16). London: Springer.

Van Baar, H. (2009). Scaling the Romani grassroots: Europeanization and transnational networking. In F. Jacobs and J. Ries (Eds.). Romani/Gypsy cultures in new perspectives, 2nd Ed. (pp. 217-241). Leipzig: Leipziger Universitatsverlag.

Verseck, K. (2014, February, 21). No help for Hungary's Roma murder victims. Deutsche Welle. Retrieved from http://www.dw.de/no-help-for-hungarysroma-murder-victims/a-17448323

Wasko, M. \& Faraj, S. (2000). "It is what one does": Why people participate and help others in electronic communities of practice. Journal of Strategic Information Systems, 9(2), 155-173.

Wenger, E. (1998). Communities of practice: Learning, meaning, and identity. Cambridge, MA: Cambridge University Press.

Wodak, R. (1995). Critical linguistics and critical discourse. In J. Verschueren, J. Ostman, \& J. Blommaert (Eds.), Handbook of pragmatics (pp. 204210). Philadelphia: John Benjamins.

Working for a more inclusive policy towards migrant Roma in France. (2013, October 18). Retrieved from Http://www.ohchr.org/EN/NewsEvents/Pages/Wor kingforamoreinclusivepolicytowardsmigrantRomainFrance.aspx\#sthash.A03F9Fi9.dpuf 
World Bank. (2005). Roma in an expanding Europe: Breaking the poverty cycle. Retrieved from http://siteresources.worldbank.org/EXTROMA/Res ources/roma_in_expanding_europe.pdf

Wright, S. \& Eccles, L. (2010). Pregnant 12-year-old found in Roma raid: Six arrests as child-trafficking ring is smashed. The Daily Mail. Retrieved from http://www.dailymail.co.uk/news/article-
1320046/Pregnant-12-year-old-Roma-raid-Sixarrests-child-trafficking-ring-smashed.html

Ziegler, M. (2008). Eugenic feminism: Mental hygiene, the Women's Movement, and the campaign for eugenic legal reform, 1900-1935. Harvard Journal of Law \& Gender, 31, 211-236. Retrieved from http://www.law.harvard.edu/students/orgs/jlg/vol 311/211-236.pdf

\section{About the Author}

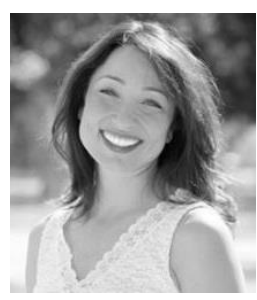

Dr. Mary Christianakis

Mary Christianakis is an Associate Professor of Language, Literacy and Culture in the Critical Theory and Social Justice Department at Occidental College. Her main areas of research include education, childhood, and juvenile justice. She has published in numerous journals, including Urban Education, Journal of Educational Controversy, Perspectives on Urban Education, Teacher Education Quarterly, Journal of Inquiry and Action in Education, and Research in the Teaching of English, and her work appears in over a dozen edited volumes. 